\title{
Is International Law a European Conspiracy?
}

Mark Weston Janis

University of Connecticut School of Law

Follow this and additional works at: https://opencommons.uconn.edu/law_papers

Part of the International Law Commons

\section{Recommended Citation}

Janis, Mark Weston, "Is International Law a European Conspiracy?" (2007). Faculty Articles and Papers. 526.

https://opencommons.uconn.edu/law_papers/526 


\section{Book Reviews}

\section{Is International Law a European Conspiracy?}

Asked by the International Community Law Review to read and comment on B.S. Chimni's "Third World Approaches to International Law,"' I was struck by how similar Chimni's critique of modern international law is to a criticism of international law that might be made by an American or Chinese or Russian realist. At first, I thought, more or less: "poor old international law - yet another 19th century liberal construct attacked both by left and by right." But, on reflection, deciding to evaluate such critiques on their own terms, I concluded that international law does seem too often to offer too much community and too little sovereignty both to left-leaning "weak" states of the Third World and to right-leaning "strong" states of the bigger powers, the United States, China, and Russia. This seems to leave the "middling" states, especially many European states, in between. For many Europeans, international law as it is may seem just about right. So perhaps both Dr. Chimni and the realists have a point - international law is, in a way, a European conspiracy, a movement of the middle against the weak à la Dr. Chimni, and the strong à la the realists. If so, perhaps the task of transforming international law is on the shoulders of the Europeans. Can they remodel the discipline so as to attract weak and strong states, as well as their own?

Let me use Dr. Chimni's essay as my template. It appears that by "third world," a term he uses well over a hundred times, he means those countries that were once the colonies of the 17th, 18th, 19th, and 20th century European imperial powers: Spain, Portugal, Great Britain, France, Russia, the Netherlands, Belgium, Germany, and Italy. Of course, the present territory of the United States was, for almost two centuries made up of what were European colonies - British, Dutch, French, Spanish, Russian, and Swedish. China, too, was partially colonized in the 19 th and 20th centuries, especially by the Japanese, Russians, and British. Only Russia of the nowadays strong states was, more or less, free of colonization, and indeed, itself an imperial power both on its European and on its Asian frontiers. On behalf of the "third world," Dr. Chimni launches eleven criticisms against modern international law. Most of his critiques seem to be shared by strong state realists. Let me look at Dr. Chimni's critiques in turn.

1) B.S. Chimni, Third World Approaches to International Law: A Manifesto, The Third World and International Order: Law, Politics And Globalization, pp. 47-73, ed. by A. Anghie, B. Chimni, K. Mickelson and O. Okafor (Leiden, Martinus Nijhoff Publishers, 2004). 
First, Dr. Chimni objects that "international law is now in the process of creating and defining the 'democratic State."' $\mathrm{He}$ considers this a sham meant to facilitate the transfer "through 'voluntary' undertaken obligatory, national sovereign economic space (pertaining to the fields of investment, trade, technology, currency, environment, etc.) to international institutions that enforce the relevant rules." ${ }^{3}$ This seems to be much the same criticism made by realists who wish to keep economic decisions within national government control.

Second, Dr. Chimni attacks international law because it "now aspires to directly regulate property rights [to achieve] the internationalization of property rights." ${ }_{4}$ This critique would not be entirely shared by some realists who might support the protection of private property no matter where located.

Third, he critiques international law because it "inter alia lays down rules with regard to the sales of goods, market access, government procurement, subsidies, and dumping." 5 Here realists would join him part-way, glad to see international trade facilitated but unwilling to cede national economic sovereignty.

Fourth, Dr. Chimni attacks the fact that "international law increasingly requires the 'deterritoralization of currencies' subjecting the idea of a 'national currency' to

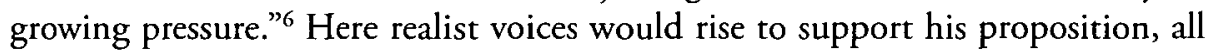
keen to maintain national currency control.

Fifth, Dr. Chimni laments "the internationalization of the discourse of human rights." "This internationality of human rights has led, in his opinion, to unwanted international interference in internal control of human rights discourse. Such a lament is, of course, shared by strong state realists.

Sixth, he complains that "labor market deregulation prescribed by international financial institutions and international monetary law has caused the deterioration of the living conditions of third world labor." ${ }^{8}$ This is not a realist complaint.

Seventh, Dr. Chimni objects to the tendency of international jurisdiction to make "a hash of geopolitical boundaries," giving as an example the prosecution of the Pinochet case. ${ }^{9}$ This objection would be happily accepted by realists, concerned as they are to insulate their national legal processes from outside influence.

Eighth, Dr. Chimni objects to the "proliferation of international tribunals that subordinate the role of national legal systems in resolving disputes." ${ }^{10}$ Interna-

\footnotetext{
2) Id. at 52 .

3) Id. at 53 .

4) Ibid.

5) Id. at 54-55.

6) Id. at 55 .

7) Ibid.

8) Id. at 56 .

9) Id. at 57 .

10) Ibid.
} 
tional tribunals, like the International Criminal Court are, as is well-known, distrusted by U.S. realists. And, in more than 80 years, neither Russia nor China has ever submitted a case to the jurisdiction of the International Court of Justice or its predecessor, the Permanent Court of International Justice.

Ninth, he regrets that "the State is no longer the exclusive participant in the international legal process," citing especially the use of a lex mercatoria. ${ }^{11}$ Given the antiquity of the lex mercatoria, this is a curious objection, unless it is simply an elaboration of the third objection about common economic rules or the seventh objection about the globalized jurisdiction making a "hash" of global boundaries.

Tenth, Dr. Chimni rejects international law's "refusal to affirmatively differentiate between States at different stages of the development process... There is no longer space for recognizing the concerns of States and peoples subjected to long colonial rule."12 This would be rejected by US and Russian realists, though the Chinese government might embrace that aspect of the objection that would support lower environmental standards for developing countries for the U.N.

Eleventh, he objects to "the privatization of the United Nations system," by which he means corporate, rather than state financial support of the U.N."13 It is doubtful that realists would want to see private, rather than state support of the United Nations.

For the most part, then, Dr. Chimni's critique of modern international law is in tune with the melodies of US, Russian, and Chinese realists. They all share at least eight of Dr. Chimni's objections to modern international law: international law interferes with national sovereignty in the name of democracy; it interferes with national sovereignty to achieve international economic control; it interferes with national sovereignty to allow international control of currencies; it interferes with national sovereignty to promote human rights; it interferes with national sovereignty by making a jurisdictional hash out of domestic legal systems; it interferes with national sovereignty by giving power to international tribunals; it interferes with national sovereignty by denying states the right to be the exclusive participant in international legal process; and it interferes with national sovereignty by privatizing the United Nations. Only with respect to three issues - the international protection of private property, the effect of international markets on labor relations, and the failure to accord special economic treatment to third world states - does it seem that Dr. Chimni and the strong state realists might disagree in opposing modern liberal international law. 
Though Dr. Chimni and the realists may agree, by and large, on their opposition to modern international law, they probably do so for different reasons. Dr. Chimni feels that international law is too strong for the weak. The realists believe that international law is too strong for the strong. This leaves many Europeans as international law's best friends. There are also those in the third world, who Dr. Chimni chides as "the ruling elite," who are becoming "an integral part of an emerging transnational ruling elite that seeks to establish the global rule of transnational capital on the pretext of pursing 'national interests"' 14 and those in the United States, Russia, and China whom the neo-conservatives similarly see as betraying national interests for international community values.

So, is international law really a European conspiracy with some hangers on in the Third World and the big powers? Are Dr. Chimni, U.S., Russian, and Chinese realists right, for their own reasons, that those in the Third World and those in the United States, Russia, and China who promote international law are actually tools of some sort of a European conspiracy, who might be a threat to national sovereign interests?

Plainly, it is easier for one to be "for" international law, if one comes from one of the many middling European states whether largish - Britain, France, Germany, Italy, Spain - or smallish - The Netherlands, Belgium, Ireland, Denmark, Sweden, Norway, Finland, Switzerland, Portugal, Poland, the Czech Republic, Slovakia, Hungary, Estonia, Latvia, Lithuania. In all these states, there seems to be a natural coincidence of the virtues of international law with national interests. There can be economic or strategic differences, but in many cases the typical European state and its nationals stand to benefit from a stable world economy and polity, where community interests sometimes prevail over national interests.

How different is the situation in either the weak states promoted by Dr. Chimni or in the strong states promoted by the realists? As Dr. Chimni and the strong state realists argue, often times more will be lost than gained in any trade off between the values of the international community and the sovereign interests of national states. International law may well be less advantageous to both weak states and strong states than to middling states.

Dr. Chimni has written a "manifesto" urging weak states to be firm in making tough demands on international law. Of course, he may be right for weak states, but his manifesto may be just as right for strong states. Ought Dr. Chimni's manifesto spur the middling states, and especially European international lawyers, to recognize such challenges from left and right? Sometimes, there may be too much outrage from the Europeans about any opposition to international law and too little accommodation. International law may need to put its best foot forward and the logical place for that step to begin is from international law's

14) Id. at 51. 
natural allies, the Europeans. Perhaps a little more European conspiracy for international law would be a good thing.

\author{
Mark Weston Janis \\ William F. Starr Professor of Law \\ University of Connecticut School of Law
}

